\title{
The Rumen Flagellate Piromonas communis: Its Life-history and Invasion of Plant Material in the Rumen
}

\author{
By C. G. ORPIN \\ Biochemistry Department, Agricultural Research Council, Institute of \\ Animal Physiology, Babraham, Cambridge CB2 $4 A T$
}

(Received 29 September 1976)

\begin{abstract}
SUMMARY
The rumen flagellate Piromonas communis is the zoospore of a phycomycete fungus inhabiting the rumen. Zoosporogenesis was stimulated by a dietary component (the inducer), and inhibited by compounds affecting membrane structure and function, but not by inhibitors of protein synthesis. The zoospores showed taxis towards the tissues surrounding the inflorescence of Lolium perenne L. in the rumen, invading principally the stomata and damaged tissues. The zoospores germinated on this substratum and the rhizoids of the developing vegetative stage penetrated the tissue, taking up ${ }^{14} \mathrm{C}$ from labelled plant material, which was incorporated into the fungal cells. The conditions for maximum flagellate production $\left(39^{\circ} \mathrm{C}\right.$, $\mathrm{pH} 6 \cdot 0$ to $7 \cdot 0$, high concentration of $\mathrm{CO}_{2}$, absence of $\mathrm{O}_{2}$ ) resembled those found in the rumen. The organism was cultured in an undefined medium in vitro in the absence of other flagellates.
\end{abstract}

\section{INTRODUCTION}

Two species of rumen flagellates, Neocallimastix frontalis and Sphaeromonas communis, were shown to be the zoospores of species of phycomycete fungi (Orpin, 1975, 1976a, 1977b). The vegetative phases of these organisms live free in the rumen fluid. Neocallimastix frontalis flagellates may also be attracted to and germinate on plant particles, especially inflorescence tissue, whilst the vegetative phase grows on and takes up carbon from this tissue (Orpin, I977a).

Liebetanz (1910) described a flagellate resembling $S$. communis, but larger and more elongate, which he named Piromonas communis. Subsequent references in the literature are rare, but Braune (I913) described the species more fully. Both Liebetanz and Braune considered $\boldsymbol{P}$. communis to be a species of flagellate protozoon, but Kudo (I954) did not mention the genus Piromonas in his treatise on the protozoa. The species is less common than $N$. frontalis or $S$. communis in the sheep at the author's laboratory, but shows similar population density fluctuations in response to the ingestion of food by the host animal to those shown by $N$. frontalis and $S$. communis (Orpin, 1974, 1976a, $b$ ). The demonstration that the sporangia of $P$. communis contain chitin (Orpin, $1977 b$ ) showed that, like $N$. frontalis and $S$. communis, it was also a species of Phycomycete. This paper describes the life-history and morphology of the organism, together with its relationship with the ingested food of the host animal.

\section{METHODS}

Animals. The sheep used were Clun Forest wethers, each fitted with a permanent rumen cannula, and fed I $\mathrm{kg}$ hay chaff and $\mathrm{I00} \mathrm{g}$ rolled oats once daily. Defaunation was by a method modified from that of Abou Akkada et al. (1968), using dioctyl sodium 
sulphosuccinate. Food was withdrawn on the day dioctyl sodium sulphosuccinate (Io g) was administered; I $\mathrm{kg}$ hay was fed on the next day and $\mathrm{Io} \mathrm{g}$ manoxol was administered. Normal feeding was resumed on the third day. Rumen phycomycetes were removed by the method of Orpin (1977a) using actidione.

Sampling and counting. Rumen fluid was sampled by aspiration and the flagellates were counted microscopically as described by Orpin (1976a) for $S$. communis. In the presence of $S$. communis, $P$. communis flagellates could be distinguished by their more rapid movement, larger size and, usually, by their elliptical shape. In the absence of other rumen phycomycetes, all observed sporangia were assumed to be those of $P$. communis.

Preparation of rumen fluid fractions. The rumen fluid used both for experiments in vitro and for counting population densities after growth in vivo was strained through one layer of muslin before use, and designated fresh rumen fluid (FRF). The maximum particle size present after straining was $550 \mu \mathrm{m}$. The material retained was designated the coarse food particle (CFP) fraction. For all experiments in vitro FRF originated from defaunated sheep containing $P$. communis as the sole phycomycete. The absence of ciliate protozoa and other phycomycetes facilitated the counting of both sporangia and $P$. communis flagellates. FRF was centrifuged at $1000 \mathrm{~g}$ for $\mathrm{I} 5 \mathrm{~min}$ at room temperature and the sediment was washed twice with and suspended in centrifuged rumen fluid (CRF; see below). This suspension was designated the large particulate (LP) fraction. The supernatant fluid was then re-centrifuged at $20000 \mathrm{~g}$ for $\mathrm{I} \mathrm{h}$ at $2{ }^{\circ} \mathrm{C}$ : this supernatant fluid was designated centrifuged rumen fluid (CRF). CRF was sterilized by autoclaving at $115{ }^{\circ} \mathrm{C}$ for $20 \mathrm{~min}$. Reduced CRF was prepared by aseptically adding $5 \mathrm{ml}$ filter-sterilized $2 \%$ L-cysteine hydrochloride (neutralized immediately before use with I $\mathrm{M}-\mathrm{NaOH}$ ) to each $\mathrm{IOO} \mathrm{ml}$ sterile CRF.

Extraction of inducer. The stimulatory component of the diet was prepared by the methods of Orpin (1974). The volume of the final aqueous extract was adjusted so that I $\mathrm{ml}$ represented the extract from $\mathrm{I} g$ dry wt oats. This extract was stored under nitrogen at $-20^{\circ} \mathrm{C}$, and is referred to as inducer. Extraction from the rumen particulate material was described by Orpin (1975).

Effect of $p H$, temperature and gas phase on the induction of sporogenesis in vitro. The methods were those of Orpin (1976a) for $S$. communis.

Culture media. Medium I contained (g per $100 \mathrm{ml}$ ): CRF, Io; $\mathrm{NaHCO}_{3}, 0.65 ; \mathrm{KH}_{2} \mathrm{PO}_{4}$, $0.5 ; \mathrm{K}_{2} \mathrm{HPO}_{4}, 0.64 ; \mathrm{NaCl}, 0.64 ; \mathrm{CaCl}_{2} .2 \mathrm{H}_{2} \mathrm{O}, 0.06 ; \mathrm{MgSO}_{4} .7 \mathrm{H}_{2} \mathrm{O}, 0.0 \mathrm{I}$; glucose, 0.02 ; and L-cysteine hydrochloride, 0.02 . This was autoclaved, allowed to cool to $50^{\circ} \mathrm{C}$ and then molten sterile agar $(0.05 \mathrm{~g})$, streptomycin sulphate (0.0I $\mathrm{g}$ ) and sodium benzylpenicillin (I0000 i.u.) dissolved in sterile water were added. The medium was allowed to gel under $\mathrm{CO}_{2}$ in $12.5 \times$ $\dot{I} \cdot 25 \mathrm{~cm}$ rimless test tubes. Three grains of barley and the attached awns, cut to a suitable length to fit the tube, were then inserted in the medium. Medium II contained the same constituents as medium I, excluding the barley awns, and supplemented with cellobiose $(0.05 \mathrm{~g})$ and yeast extract $(0.025 \mathrm{~g}$; Oxoid). Stock cultures were maintained on both media.

Isolation and culture in vitro. FRF ( $10 \mathrm{ml}$ ) containing $P$. communis and $N$. frontalis was added to a tube containing inducer extracted from $\mathrm{I} g$ oats, and a single awn of barley was added. The tube was stoppered, incubated at $39^{\circ} \mathrm{C}$ for $2 \mathrm{~h}$, and the awn removed, washed with sterile CRF and placed in a tube of culture medium I. The awn had germlings of both $P$. communis and $N$. frontalis attached; however, in medium I the flagellates of $N$. frontalis released from mature sporangia grown on the awn, failed to germinate, whereas $P$. communis flagellates germinated and grew weakly in the surrounding medium and strongly on the barley awns. After $48 \mathrm{~h}$, a single infected barley awn was transferred to fresh medium; no $N$. frontalis was identified in this culture. Transfer of the medium containing vegetative 
growth of $P$. communis to fresh medium II, and many transfers in that medium at 2-day intervals, did not free the culture of bacteria; $P$. communis, the sole phycomycete, grew vigorously. Both media could be stored for up to 4 days at $4{ }^{\circ} \mathrm{C}$. Storage of cultures at 4 or $-20^{\circ} \mathrm{C}$ for $24 \mathrm{~h}$ resulted in a loss of viability, although cultures maintained at $22{ }^{\circ} \mathrm{C}$ were still viable after $24 \mathrm{~h}$ but not after $48 \mathrm{~h}$.

Establishment of $P$. communis as the sole phycomycete in the rumen. Cultures of $P$. communis $(500 \mathrm{ml})$ were added via the rumen cannula to the rumen of a sheep devoid of phycomycetes. After 2 to 3 weeks a stable population density of $P$. communis had been established. Provided the sheep were isolated from physical contact with sheep containing other phycomycetes, and no transfer of bedding or food from these sheep occurred, sheep could be maintained in this state for up to five weeks.

Sources of plant material. Barley (Hordeum distichon) plants were given by Mr Hansen of the Agricultural Research Council Plant Breeding Institute, Trumpington, Cambridge. Seed of Pennisetum longistylum Hort. was obtained from Thomson and Morgan, Ipswich, Suffolk and grown in garden soil. Other material was from the grounds of the laboratories.

Incubation of plant tissues in the rumen. Tissue samples were incubated in the rumen in nylon mesh bags (maximum aperture $46 \mu \mathrm{m}$; Orpin, $1977 a$ ). The attraction of $P$. communis to different tissues was determined by incubating the tissue in the rumen for $19 \mathrm{~h}$, and counting the number of flagellates produced from each g dry wt of tissue after exposure to the inducer in vitro (Orpin, $1977 a$ ).

Preparation of ${ }^{14} \mathrm{C}$-labelled barley awns and measurement of radioactivity was carried out as described by Orpin (1977a).

\section{RESULTS}

\section{Observations in vivo}

Piromonas communis flagellates (Fig. I) were observed in $35 \%$ of the sheep examined. They occurred both in sheep with normal rumen microbial populations and in those devoid of ciliate protozoa. Pre-feeding population densities ranged from $\mathrm{I} \cdot 4 \times 10^{3}$ to $\mathrm{I} \cdot 6 \times 10^{4} \mathrm{ml}^{-1}$. No sheep was found in which $P$. communis was the sole phycomycete flagellate, although it occurred with $N$. frontalis in $10 \%$ of the sheep and with $S$. communis and $N$. frontalis in another $25 \%$. Piromonas communis flagellates were present at all times during the day, but their population density fluctuated significantly over the feeding period of the host animal. This fluctuation was usually a I0- to 45 -fold increase (compared with the pre-feeding minimum population density) within $90 \mathrm{~min}$ of feeding, followed by a decline to pre-feeding levels within 4 to $6 \mathrm{~h}$ (Fig. 2). These fluctuations also occurred after the addition of inducer extracted from $300 \mathrm{~g}$ dry wt oats to the rumen in place of the normal diet. Within $\mathrm{I} \cdot 5 \mathrm{~h}$ of feeding or addition of inducer to the rumen, no phycomycete sporangia could be detected. It was not possible to differentiate with certainty between the sporangia of $S$. communis and those of $P$. communis when both were present in the same rumen; two sheep were therefore prepared with $\boldsymbol{P}$. communis as the sole phycomycete. In experiments using only these sheep, it was possible to identify the $\boldsymbol{P}$. communis sporangia and to obtain information regarding their population density. As the population density of the flagellates increased, that of the sporangia decreased (Fig. 3); the population density of sporangia more than $30 \mu \mathrm{m}$ long increased 8 to $\mathrm{I} 6 \mathrm{~h}$ after feeding and reached a maximum at $\mathrm{I} 4$ to $\mathrm{I} 6 \mathrm{~h}$ (Fig. 4 ). The sporangia in rumen fluid occasionally possessed a short length of rhizoid (Fig. 5a); most were either oval or cylindrical, up to $72 \mu \mathrm{m}$ long often with a squared end (Fig. $5 b$ ) suggesting that they had probably been broken from their rhizoid in the rumen or during the preparation of the rumen fluid for examination. Attachment of mature sporangia to particles in the rumen 

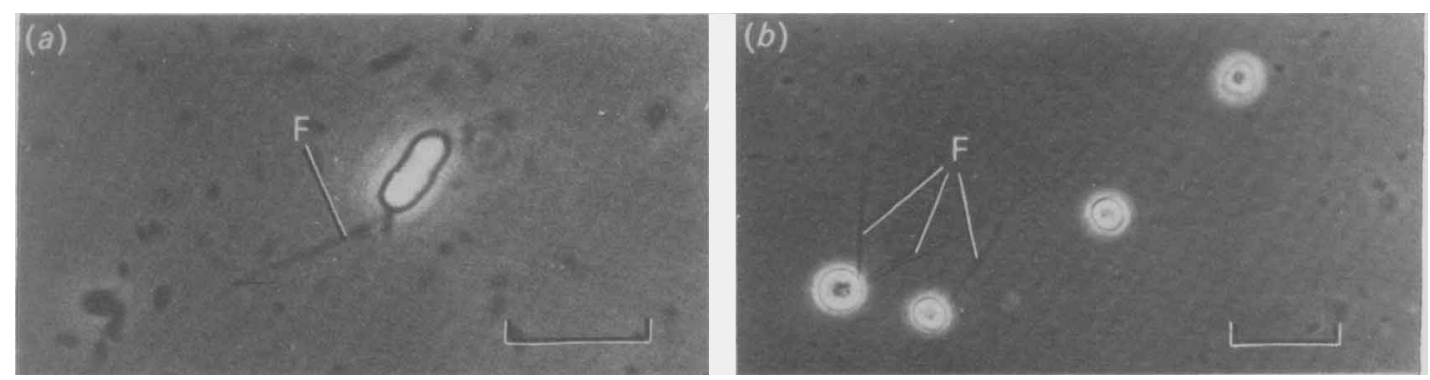

Fig. I. Flagellates of $P$. communis. Living preparation at $(a) 39^{\circ} ; \mathrm{C}(b) 22^{\circ} \mathrm{C}$, including one abnormal flagellate with three flagella. F, flagella. Bar marker represents $20 \mu \mathrm{m}$.

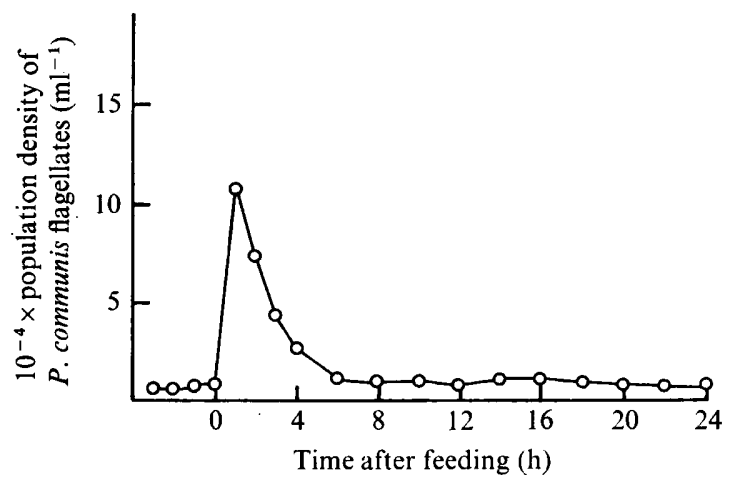

Fig. 2. Population density of $P$. communis flagellates over $24 \mathrm{~h}$. The sheep was fed at zero time. Average of three experiments.

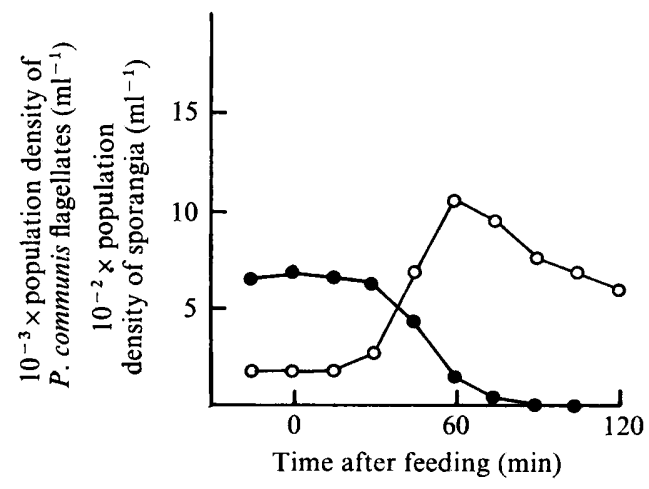

Fig. 3

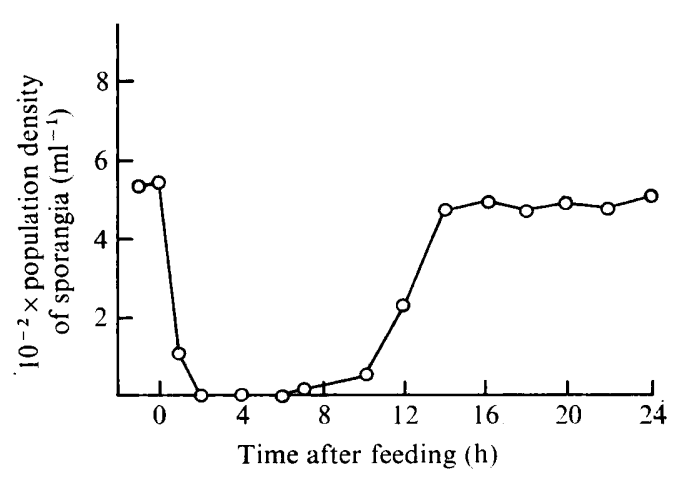

Fig. 4

Fig. 3. Population density of $\boldsymbol{P}$. communis flagellates $(\bigcirc)$ and sporangia $>30 \mu \mathrm{m}(O)$ over the feeding period of the host animal. The sheep was fed at zero time. Average of three experiments.

Fig. 4. Population density of $P$. communis sporangia $>30 \mu \mathrm{m}$ over $24 \mathrm{~h}$. The sheep was fed at zero time. Average of three experiments. 

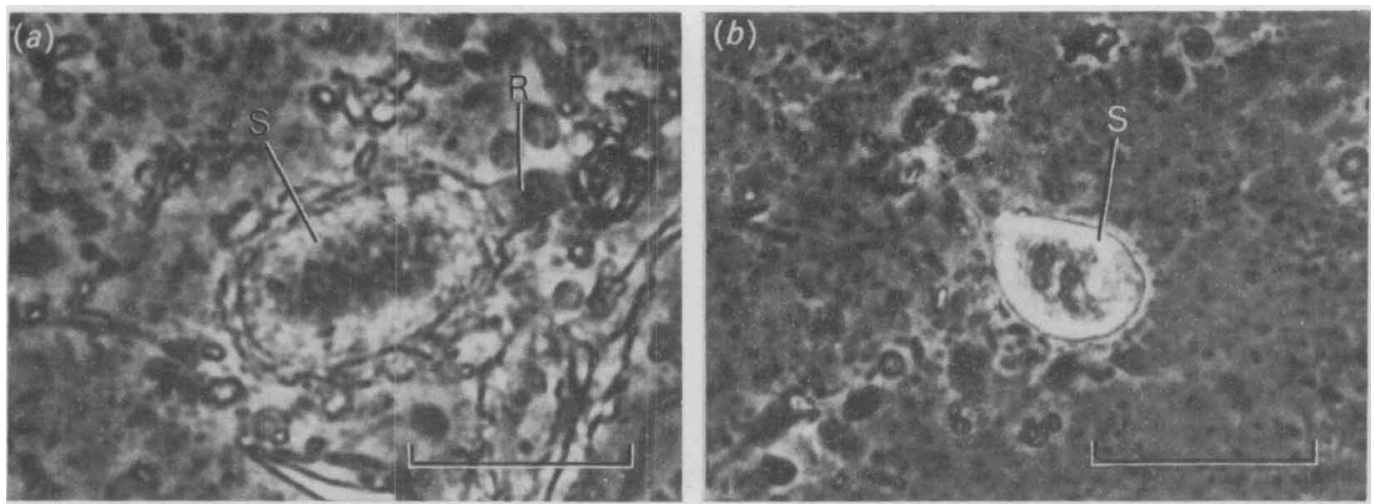

Fig. 5. Sporangia of $\boldsymbol{P}$. communis in rumen fluid: $(a)$ possessing a short rhizoid; $(b)$ showing a square end to the cell. S, sporangium; R, rhizoid. Bar marker represents $50 \mu \mathrm{m}$.

fluid was rarely observed, although small sporangia (20 to $30 \mu \mathrm{m}$ ) were often seen in association with particulate material. Examination of sporangia in rumen fluid $\mathrm{I} h$ after the addition of inducer to the rumen showed many that were in an advanced state of internal differentiation; further incubation in vitro at $39{ }^{\circ} \mathrm{C}$ resulted in the liberation of $P$. communis flagellates from these sporangia.

Conditions for $P$. communis flagellate production in samples of rumen fluid incubated with inducer

Effect of concentration of inducer. Sporangia of $P$. communis in FRF showed $100 \%$ differentiation and release of flagellates after incubation with inducer extracted from $40 \mathrm{mg}$ dry wt oats (ml fluid) ${ }^{-1}$. In subsequent experiments an excess of inducer prepared from 100 mg dry wt oats (ml FRF) ${ }^{-1}$ was used.

Effect of temperature. FRF incubated with inducer at temperatures from 25 to $50^{\circ} \mathrm{C}$ for I h showed a peak in flagellate production at $39^{\circ} \mathrm{C}$. Results, given as a percentage of those flagellates produced at $39{ }^{\circ} \mathrm{C}$, were: $25^{\circ} \mathrm{C}, 5 ; 30{ }^{\circ} \mathrm{C}, \mathrm{I} 8 ; 35^{\circ} \mathrm{C}, 32 ; 39{ }^{\circ} \mathrm{C}, 100 ; 45^{\circ} \mathrm{C}, \mathrm{I} 5$; and $50{ }^{\circ} \mathrm{C}$, 0 .

Effect of storage of FRF. FRF was stored for various periods of time and then incubated with inducer extracted from $100 \mathrm{mg}$ dry wt oats $\mathrm{ml}^{-1}$. Flagellate production in FRF after storage, as a percentage of that at zero time, was: $0 \mathrm{~h} 100 ; 0.5 \mathrm{~h}, 97 ; \mathrm{I} \mathrm{h}, 82 ; 2 \mathrm{~h}, 65 ; 3 \mathrm{~h}, 42$; $4 \mathrm{~h}, \mathrm{I} 2$; and $5 \mathrm{~h}, 2$. The activity of the inducer was checked at each stage against fresh FRF and found to be undiminished. The FRF stored at $39^{\circ} \mathrm{C}$ therefore showed a rapid decrease in the efficiency of added inducer.

Effect of $p H$. Maximum production of flagellates in FRF incubated with inducer occurred at pH 6 to 7; outside these limits flagellate production diminished rapidly. Results were $(\mathrm{pH}$, and flagellate production as a percentage of those produced at $\mathrm{pH} 6.5): 5.5,25$; $6 \cdot 0,95 ; 6 \cdot 5,100 ; 7 \cdot 0,92 ; 7 \cdot 5,45 ; 8 \cdot 0,27$.

Effects of inhibitors. Polymixin B and cytochalasin B completely inhibited fiagellate production. The results for polymixin B were [concentration $\left(\mu \mathrm{g} \mathrm{ml}^{-1}\right)$, and production of $P$. communis flagellates as a percentage of the control]: 50,$37 ; 100,0 ; 200,0$. Similarly, results for cytochalasin B were: 50, $8 ; 100,0 ; 200$, 0. Streptomycin and actidione (protein synthesis inhibitors) did not inhibit flagellate production at $200 \mu \mathrm{g} \mathrm{ml}^{-1}$, although actidione completely inhibited growth in vitro at $8 \mu \mathrm{g} \mathrm{ml}^{-1}$. 


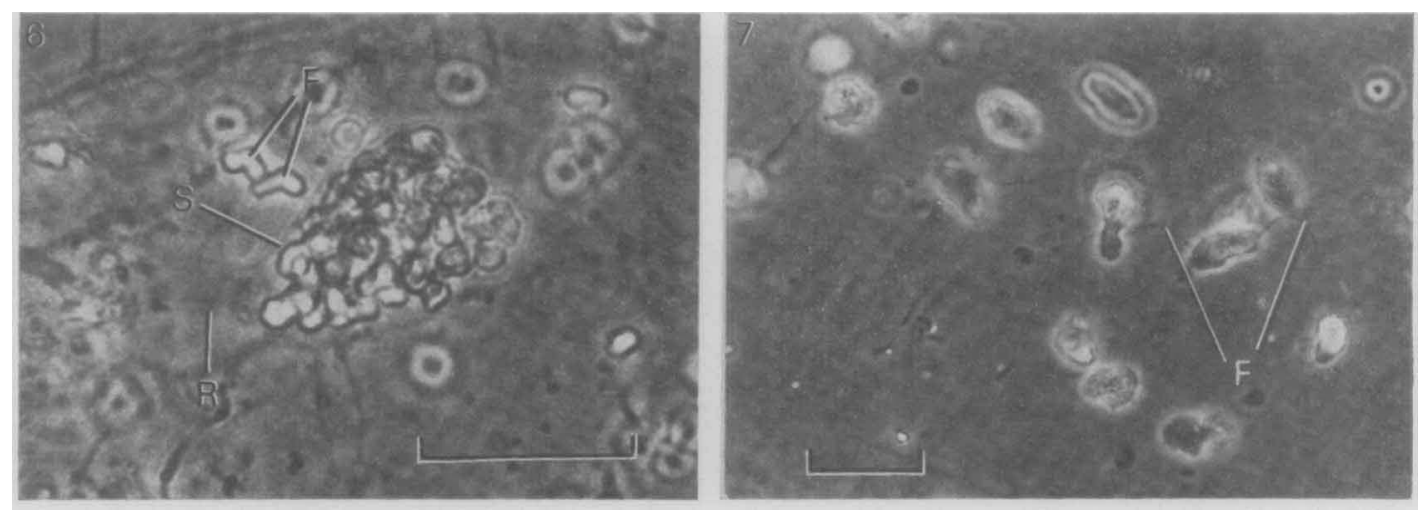

Fig. 6. Release of $\boldsymbol{P}$. communis flagellates from a sporangium cultured in vitro. F, flagellate cell; $\mathrm{S}$, sporangium wall; $\mathrm{R}$, rhizoid. Bar marker represents $50 \mu \mathrm{m}$.

Fig. 7. Amoeboid movement shown by flagellates of $P$. communis. F, flagella. Bar marker represents $20 \mu \mathrm{m}$.

Effect of gas phase. The results for different gas phases were (gas, and production of flagellates as a percentage of those produced under standard conditions): $100 \% \mathrm{CO}_{2}, 90 ; 50 \%$ $\mathrm{CO}_{2}+50 \% \mathrm{~N}_{2}, 85 ; 5 \% \mathrm{CO}_{2}+95 \% \mathrm{~N}_{2}, \mathrm{I} 5 ; 100 \% \mathrm{~N}_{2}, 4 ;$ air, $0 ; 100 \% \mathrm{O}_{2}, 0 . \mathrm{CO}_{2}$ was then bubbled for 2 min through the tubes containing $5 \% \mathrm{CO}_{2}+95 \% \mathrm{~N}_{2}, \mathrm{~N}_{2}$ alone, air or $\mathrm{O}_{2}$; the tubes were stoppered and incubated a further $\mathrm{I} h$, and the $P$. communis flagellates were counted. Total flagellate production ( $\%$ ) was: $5 \% \mathrm{CO}_{2}+95 \% \mathrm{~N}_{2}, 78 ; \mathrm{N}_{2}, 82 ;$ air, o; $\mathrm{O}_{2}, 0$. A high $\mathrm{CO}_{2}$ concentration was therefore necessary for high flagellate production; nitrogen, air and oxygen inhibited production. Nitrogen inhibition could be reversed by flushing with $\mathrm{CO}_{2}$. The non-reversibility of $\mathrm{O}_{2}$ inhibition indicated that oxygen was toxic to the reproductive stage.

\section{Morphology and life-history}

Piromonas communis flagellates. Piromonas communis flagellates grown in vitro and in vivo were of similar morphology; on release from the sporangia they were often irregular in shape (Fig. 6) but within 2 to $3 \mathrm{~min}$ became more elongate and regular with average axial dimensions of $7 \cdot 1 \times 14.6 \mu \mathrm{m}(n=50$; Fig. I $a)$ and a single flagellum of average length $28 \cdot 8 \mu \mathrm{m}(n=50)$. Little internal structure was visible under the light microscope, the cell appearing refractile and the contents granular. The cell was actively motile, with the flagellum posteriorly orientated whilst the cell was in motion. During periods of less activity the cell became more rounded, assuming the appearance of $N$. frontalis, the flagellum being laterally orientated. At low temperatures the cell became spherical and inactive (Fig. $I b$ ). Flagellates with two or three flagella were sometimes seen (Fig. I $b$ ).

Occasionally the flagellates ceased swimming, the flagellum became inert, and the cell moved in an amoeboid fashion for up to $30 \mathrm{~min}$ in rumen fluid or $2 \mathrm{~h}$ in vitro (Fig. 7). When amoeboid movement ended the cell became elongate and flagellar motility recurred.

Germination of the flagellate and growth of the vegetative stage. After $\mathrm{I}$ to $3 \mathrm{~h}$ of rapid motility in vitro, or an unknown period in vivo, the flagellates became more refractile, and the flagellum became detached. Germination then ensued by the growth of a single rhizoid (Fig. 8) from a terminal position on the cell. Occasionally the flagellum remained attached to the germinating cell in vitro. Subsequent growth of the vegetative stage was by elongation of the rhizoid and enlargement of the sporangium. After growth in vivo the sporangium was 

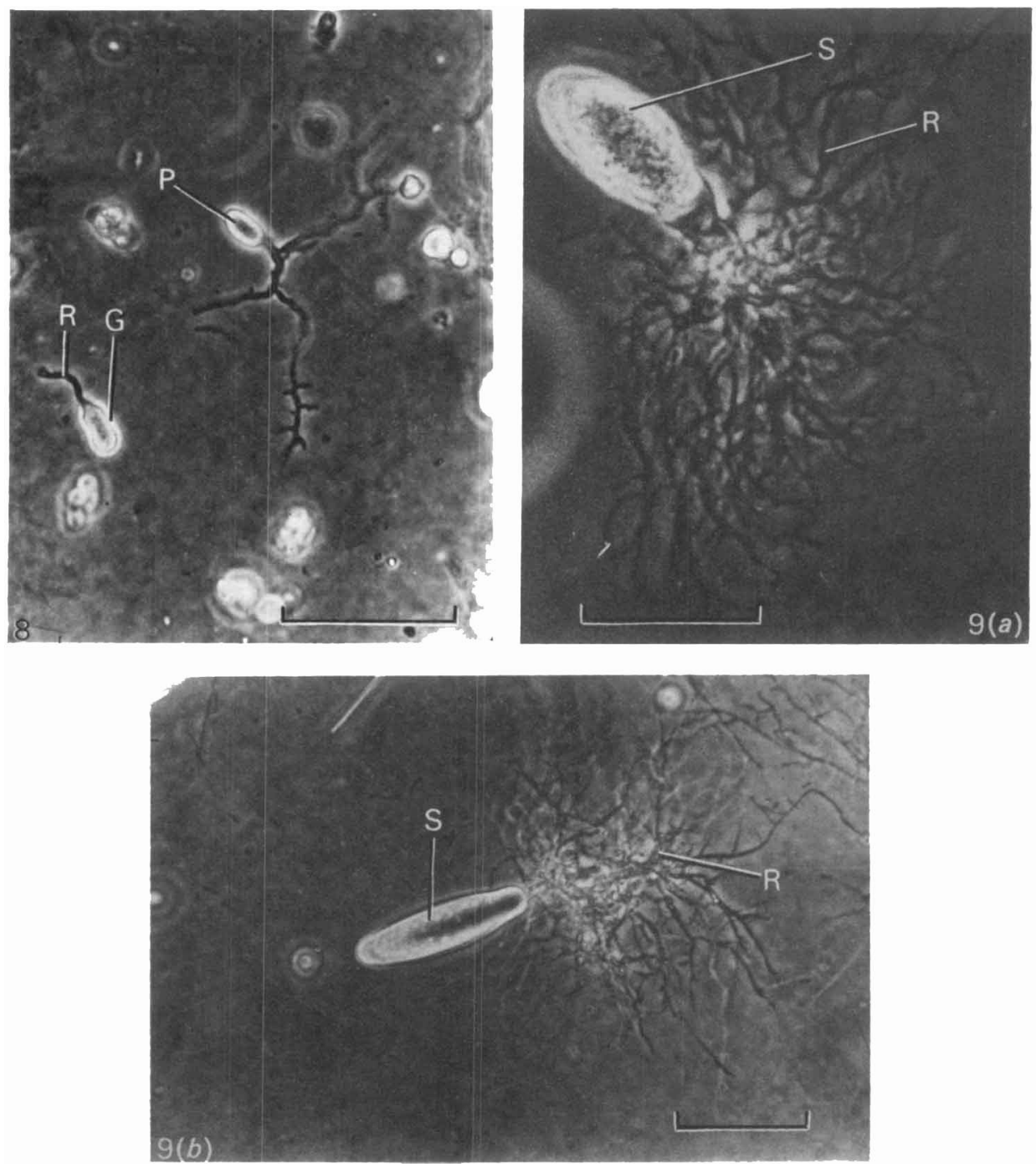

Fig. 8. Germination of $P$. communis in vitro after loss of flagella. $G$, germinating cell, $R$, rhizoid, $P$, young vegetative stage. Bar marker represents $50 \mu \mathrm{m}$.

Fig. 9. Mature vegetative stage of $\boldsymbol{P}$. communis cultured in vitro: (a) most commonly observed sporangium shape; $(b)$ elongated sporangium. S, sporangium; R, rhizoid. Bar marker represents $50 \mu \mathrm{m}$.

capable of liberating flagellates in response to the dietary component within $6 \mathrm{~h}$. The number of flagellates produced from each sporangium in vivo ranged from 2 to 78 , depending on its age.

The vegetative stages cultured in vitro in medium II always possessed a limited rhizoid system consisting of a single, non-septate highly-branched rhizoid, up to $365 \mu \mathrm{m}$ long (Fig. 9) and I I $\mu \mathrm{m}$ diam. The sporangium was cylindrical to ovoid (Figs $9 a, b$ ). Differentiation of the sporangium and release of the flagellates (Fig. 6) was frequently observed, but their release was slower than in rumen fluid, probably due to the presence of agar in culture 
Table I. Invasion of plant tissues by $P$. communis after incubation in the rumen for $19 h$

Plant species

Trifolium repens $\mathrm{L}$.

Trifolium pratense $\mathrm{L}$.

Medicago sativa $\mathrm{L}$.

Lolium multiflorum $\mathrm{L}$.

Lolium perenne $\mathrm{L}$.

Dactylis glomerata L.

Festuca ovina L.

Festuca rubra $\mathrm{L}$.

Pennisetum longistylum Hort.
Tissue

Leaves

Leaves

Leaves

Leaves

Leaves

Stem

Roots

Inflorescence

Seedhead

Leaves

Leaves

Leaves

Leaves

Seedhead
$10^{-4} \times P$. communis

flagellates produced (g dry wt tissue) $)^{-1}$

$$
\begin{gathered}
27 \cdot 6 \\
32 \cdot 4 \\
16 \cdot 6 \\
14 \cdot 2 \\
32 \cdot 4 \\
18 \cdot 6 \\
6 \cdot 2 \\
1468 \\
746 \\
34 \cdot 2 \\
27 \cdot 3 \\
41 \cdot 0 \\
36 \cdot 6 \\
827
\end{gathered}
$$

medium. In medium $I$, the rhizoids of vegetative stages growing in the agar were shorter than in medium II, having a maximum length of $240 \mu \mathrm{m}$. It was not possible to determine the extent of the rhizoid system within the barley awns in medium I; however, sporangia on the barley awns were larger $(95 \times 49 \mu \mathrm{m}$ max. $)$ than those growing free in medium I $(66 \times 35 \mu \mathrm{m}$ max.), but comparable in size with those cultured in medium II $(89 \times 45 \mu \mathrm{m}$ max.). Considerable destruction of the barley awn and accumulation of gas in the tissues was evident after incubation with $P$. communis for 3 days.

Invasion of plant material. During experiments with $N$. frontalis in normal rumen fluid it was observed that both $N$. frontalis and $P$. communis were attracted to awns of barley incubated in rumen fluid taken from the host animal before feeding and after exposure to inducer in vitro. The experiments were repeated using rumen fluid containing $P$. communis as the sole phycomycete. It was found that the flagellates attached themselves to stomata (Fig. Io $a, b$ ), lateral spikes and regions of damaged tissue. Incubation of the infected awn in medium $I$ in vitro resulted in elongation of the spore cells to form sporangia (Fig. IOc) and their subsequent broadening and enlargement (Fig. Io d). This was followed by a secondary invasion of the plant material by flagellates released from the sporangia.

Growth of $P$. communis on plant tissues incubated in the rumen. Leaves of different plants incubated in nylon mesh bags in the rumen were tested for their ability to attract $P$. communis flagellates. The extent of invasion by the flagellates was determined by the release of flagellates from the vegetative growth produced by the germinated flagellate (germling) after incubation in vitro in the presence of inducer. There were considerable differences in the degree of invasion of leaves of different plants (Table I). However, the invasion of the leaves of the grasses tested was similar. The invasion pattern towards the different tissues of Lolium perenne $\mathrm{L}$. showed a marked preference of the flagellates for invasion and growth on inflorescence tissues, whilst growth on the root tissue was small.

Uptake of ${ }^{14} C$ by $P$. communis vegetative phase from ${ }^{14} C$-labelled barley awns. The $P$. communis sporangia, which were removed from the barley awns after $20 \mathrm{~h}$ incubation in the rumen, took up I I. $2 \%$ of the initial radioactivity in the awns (Table 2 ). Considering that a loss of $45 \%$ of the radioactivity occurred during the incubation (presumably by leaching and microbial activity), this uptake into the sporangia represented $20.4 \%$ of the residual radioactivity in the awns and the entire $P$. communis vegetative growth. 

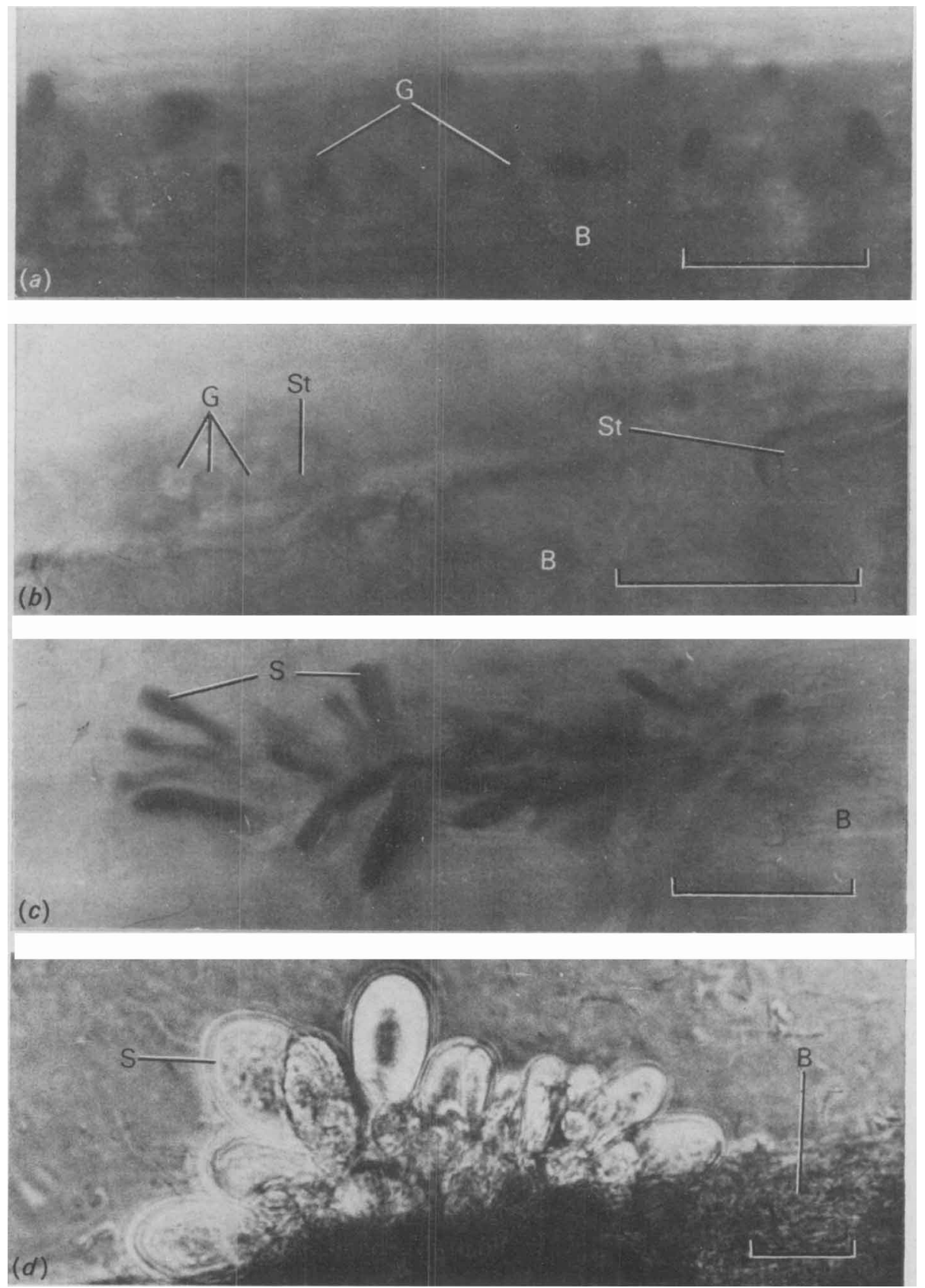

Fig. I0. Invasion of barley awn by $P$. communis: (a) appearance of awn surface after incubation with FRF containing inducer for $\mathrm{I} \mathrm{h} ;(b)$ awn surface showing occupation of one stoma by $\boldsymbol{P}$. communis germlings, another stoma is unoccupied; $(c)$ as $(a)$, but after $8 \mathrm{~h}$ incubation, showing elongated sporangia; $(d)$ as $(a)$ but incubated for $20 \mathrm{~h}$ in medium I. G, germlings; St, stoma; B, barley awn; S, sporangia. Bar marker represents $50 \mu \mathrm{m}$. 
Table 2. Distribution of ${ }^{14} C$ after growth of $P$. communis on ${ }^{14} C$-labelled barley awns incubated in the rumen

Fractions I, 2 and 3 refer to radioactivity (mg dry wt material) ${ }^{-1}$; fractions 4, 5 and 6 refer to the radioactivity removed (mg dry wt awn) ${ }^{-1}$ after incubation.

Fraction

I. Awns before incubation

2. Awn and $P$. communis growth, after incubation

3. Radioactivity lost in rumen $(I-2)$

4. Sporangia fraction

5. Control fraction (as 4, incubated in vivo in the absence of phycomycetes)

6. Sporangia (4-5)

$10^{-4} \times$ Radioactivity
(c.p.m.)
I $81 \cdot \mathrm{I}$
$99 \cdot \mathrm{I}$

$82 \cdot 0$
$23 \cdot 6$
$3 \cdot 3$
$20 \cdot 3$

\section{DISCUSSION}

Piromonas communis shares many characteristics with the rumen organisms $N$. frontalis and $S$. communis. All three organisms have vegetative reproductive stages morphologically consistent with their being members of the fungal class Phycomycetes, and the finding of chitin in the sporangia and hyphal walls of all three species (Orpin, $1977 b$ ) confirms this. The reproductive cycle in the life-history of $P$. communis was geared to the intake of food by the host animal, since a dietary component (the inducer) stimulated the sporangia to differentiate internally and liberate flagellates. Maximum flagellate production in the rumen occurred $\mathrm{I} \mathrm{h}$ after feeding or after addition of inducer to the rumen. It was less rapid than that shown by $N$. frontalis (I 5 to $20 \mathrm{~min}$ ) and of similar duration to that shown by $S$. communis (60 min) (Orpin, 1976a). Piromonas communis flagellates could be found in the rumen at any time during the day even in sheep and fed once daily. Since the inducer survived less than $6 \mathrm{~h}$ in the rumen, another factor must have been active in the rumen triggering flagellate production. In this, all three species were similar.

The pattern of invasion of different plant tissues was very similar to that shown by $N$. frontalis, which also preferentially invaded inflorescence tissue via stomata and damaged regions of that tissue. Sphaeromonas communis has not been shown to invade plant tissues in the rumen.

The flagellates of $\boldsymbol{P}$. communis and $\boldsymbol{S}$. communis were morphologically similar: both had a posteriorly oriented flagellum, and differed only in the size of the cell and its shape during periods of high motility, that of $P$. communis being elongate and that of $S$. communis, spherical. However, the vegetative stages were quite different: when cultured in the same medium, $P$. communis possessed a well developed rhizoid system whereas $S$. communis did not. In addition, $S$. communis vegetative growth included up to five spherical bodies of unknown function, associated with the sporangium (Orpin, 1976a). No body of this sort has been observed associated with $P$. communis.

Although $\boldsymbol{P}$. communis invaded inflorescence tissue in the rumen, it is probable that this tissue was not essential to maintain a high population density of the organism since the diet was essentially free of inflorescence tissue. This may explain why the vegetative stage of the organism was only rarely observed attached to plant particles in rumen fluid. However, the paucity of sporangia possessing rhizoids in fresh rumen fluid could be explained by their fracture from the rhizoids during mastication by the host animal, or during sample preparation. This was supported by the presence of large numbers of mature sporangia with 
squared ends, suggesting that fracture from the rhizoids had occurred. The other alternative, that growth of sporangia occurred without growth of a rhizoidal system, is unlikely, since no sporangium developed in this manner in culture in vitro.

The uptake of ${ }^{14} \mathrm{C}$-labelled material from barley awns incubated in the rumen showed conclusively that $P$. communis utilized the awn as a nutrient source and not merely as an anchorage point. Culture in vitro in liquid medium showed that the organism could take up soluble nutrients and that intact plant material was not essential for its growth.

The flagellates showed a specific attraction to inflorescence tissues, probably due to a chemotactic response to material leaking from the stomata and damaged tissue where germination was initiated. The only other rumen organism in which positive taxis towards specific plant tissues has been demonstrated, as far as the author is aware, is $N$. frontalis (Orpin, 1975), the flagellates of which are attracted to similar tissues.

The morphology of the flagellate and vegetative stages suggests that $P$. communis is a member of the Chytridiales of the aquatic Phycomycetes (fungi), since this morphology is common to members of this group (Sparrow, 1960). However, further nutritional and structural examinations need to be completed before its taxonomic position can be determined precisely.

\section{REFERENCES}

Abou Akmada, A. R., Bartley, E. E., Berube, R., Fina, L. R., Meyer, R. M., Hendricks, D. \& Julius, F. (I968). Simple method to remove completely ciliate protozoa from adult ruminants. Applied Microbiology I6, $1475-1477$.

Braune, R. (1913). Untersuchungen über die im Wiederkäuermagen vorkommenden Protozoen. Archiv für Protistenkunde 32, I I I-I 70.

Kudo, R. R. (1954). Protozoology, 4th edn. Illinois: Thomas Springfield.

Liebetanz, E. (1910). Die parasitischen Protozoen des Wiederkäuermagens. Archiv für Protistenkunde 19, 19.

ORPIN, C. G. (1974). The rumen flagellate Callimastix frontalis: does sequestration occur? Journal of General Microbiology 84, 395-398.

ORPIN, C. G. (1975). Studies on the rumen flagellate Neocallimastix frontalis. Journal of General Microbiology 91, 249-262.

OrPIN, C. G. (1976a). Studies on the rumen flagellate Sphaeromonas communis. Journal of General Microbiology $94,270-280$.

OrPIN, C. G. (1976b). Piromonas communis: a third species of rumen Phycomycete. Journal of Applied Bacteriology 4r, xxvii.

ORPIN, C. G. (1977a). Invasion of plant tissue in the rumen by the flagellate Neocallimastix frontalis. Journal of General Microbiology 98, 423-430.

ORPIN, C. G. $(1977 b)$. The occurrence of chitin in the cell walls of the rumen organisms Neocallimastix frontalis, Piromonas communis and Sphaeromonas communis. Journal of General Microbiology 99, 21 5218.

Sparrow, F. K., JR (1960). Uniflagellatae. Chitridiales. In Aquatic Phycomycetes, 2nd edn. pp. 42-603. Ann Arbor: University of Michigan Press. 